\title{
INDEX TO Volumes 17 AND 18 (1999-2000)
}

\section{Articles}

ANDRIEU, Claire. Women in the French Resistance: Revisiting the Historical Record (Vol. 18, No. 1, p. 13)

ARMUS, Seth. The American Menace in the Houellebecq Affair (Vol. 17, No. 2, p. 34)

BERGERON, Josée. La Politique familiale française et l'identité nationale: les familles des DOM sont-elles françaises? (Vol. 17, No. 3-4, p. 101)

BERISS, David. Culture-as-Race or Culture-as-Culture: Caribbean Ethnicity and the Ambiguity of Cultural Identity in French Society (Vol. 18, No. 3, p. 18)

BLEICH, Erik. Antiracism without Races: Politics and Policy in a "ColorBlind" State (Vol. 18, No. 3, p. 48)

CALVÈS, Gwénaële. Les Politiques françaises de lutte contre le racisme, des politiques en mutation (Vol. 18, No. 3, p. 75)

CAMISCIOLI, Elisa. Intermarriage, Independent Nationality, and the Individual Rights of French Women: The Law of 10 August 1927 (Vol. 17, No. 3-4, p. 52)

COHEN, Paul. Of Linguistic Jacobinism and Cultural Balkanization: Contemporary French Linguistic Politics In Historical Context (Vol. 18, No. 2, p. 21)

DARMON, Muriel. Les « entreprises » de la morale familiale (Vol. 17, No. 34, p. 1)

de SINGLY, François. "La fin du règne de l'enfant »: des usages savants de la norme du «bien de l'enfant» (Vol. 17, No. 3-4, p. 117)

DUBOIS, Laurent. Republican Antiracism and Racism : A Caribbean Genealogy (Vol. 18, No. 3, p. 5)

FABIANI, Jean-Louis. Tragédiens et Comédiens: les Corses et l'État français (Vol. 18, No. 2, p. 1)

FASSIN, Éric. PaCS Socialista. La Gauche et le juste milieu (Vol.17, No. 2, p. 3) 
FASSIN, Éric. Le Mariage des homosexuels: politique comparée des normes franco-américaines (Vol. 17, No. 3-4, p. 165)

FEUILLÉE-KENDALL, Pascale. Le cas Bachelot: une députée atypique. Son combat pour le Pacte civil de solidarité (Vol. 17, No. 2, p. 14)

GOJARD, Séverine. Les Soins aux jeunes enfants: entre normes de puériculture et normes familiales. Une étude de cas (Vol. 17, No. 3-4, p. 134)

HARGREAVES, Alec G. Half-Measures: Antidiscrimination Policy in France (Vol. 18, No. 3, p. 83)

KUISEL, Richard. In Memoriam: Gordon Wright (1912-2000) (Vol. 18, No. 2, p. 94)

LEFAUCHEUR, Nadine. L'accouchement "sous X": une "tradition française"? (Vol. 17, No. 3-4, p. 153)

HEUER, Jennifer. Adopted Daughter of the French People: Suzanne Lepeletier and Her Father, the National Assembly (Vol. 17, No. 3-4, p. 31)

LENOIR, Remi. La Question familiale: familialisme d'Église, familialisme d'État (Vol. 17, No. 3-4, p. 75)

LIMORE, Yagil. La Milice française (Vol. 17, No. 1, p. 37)

LONGUET, Patrick. Crise au Front national: chronique d'un divorce annoncé (Vol. 17, No. 1, p. 17)

MENON, Anand. Domestic Constraints on French NATO Policy (Vol. 18, No. 2, p. 49)

MILES, William F. S. Abolition, Independence, and Soccer: Premillennial Dilemmas of Martinican Identity (Vol. 17, No. 2, p. 23)

REVEL, Jacques. Histoire vs Mémoire en France aujourd'hui (Vol. 18, No. 1 p. 1)

ROYALL, Frédéric. Protestations collectives d'une minorité socioéconomique en France (Vol. 18, No. 2, p. 69)

SAADA, Emmanuelle. Abdelmalek Sayad and the Double Absence: Toward a Total Sociology of Immigration (Vol. 18, No. 1, p. 28)

SCHAIN, Martin. A. The National Front and the French Party System (Vol. 17 , No. 1, p. 1)

SCHWOK, René. La France et l'intégration européenne: une évaluation du «paradigme identitariste » (Vol. 17, No. 1, p. 56)

SCOTT, Joan Wallach. Feminist Family Politics (Vol. 17, No. 3-4, p. 20)

ZUBER, Martha. Profession: "Messager culturel." Entretien avec Laure Adler, Directrice de France-Culture (Vol. 18, No. 2, p.86)

\section{Dossier: Charting the Future of French Farming}

CLERC, François. Craintes et espoirs des agriculteurs français (Vol. 18, No. 1, p. 71)

HERVIEU, Bertrand. La loi d'orientation agricole comme enjeu de société (Vol 18, No. 1, p. 81)

ROGERS, Susan Carol. Farming Visions: Agriculture in French Culture (Vol. 18 , No. 1, p. 50) 
Forum: Le Nouvel ESPRIT DU CAPITALISMe, LuC BOLTANSKI AND Ève Chiapello

BOLTANSKI, Luc and CHIAPELLO, Ève. A Reply (Vol. 18, No. 3, p. 129)

KOGUT, Bruce. Making Networks Accountable (Vol. 18, No. 3, p. 123)

PIORE, Michael J. Deconstructing the Reconstruction of Capitalism (Vol. 18, No. 3, p. 109)

REID, Donald. Not Your Father's Capitalism (Vol. 18, No. 3, p. 115)

ROSS, George. Capitalism and Its Spirits? (Vol. 18, No. 3, p. 105)

\section{Review Essays}

CARON, Vicki. Ordinary Antisemitism and Vichy Anti-Jewish Policy. Review of Un antisémitisme ordinaire: Vichy et les avocats juifs (1940-1944) by Robert Badinter and Vichy Law and The Holocaust in France by Richard H. Weisberg (Vol. 18, No. 2, p. 104)

CONKLIN, Alice L. French Culture(s) After Empire. Review of Post-Colonial Cultures in France by Alec G. Hargreaves and Mark McKinney, eds. and Vers un multiculturalisme français, l'empire de la coutume, by Jean-Loup Amselle. (Vol. 18, No. 3, p. 143)

FRADER, Laura L. Engendering French History Between the World Wars. Review of France Between the Wars: Gender and Politics by Siân Reynolds, Civilization Without Sexes: Reconstructing Gender in Postwar France, 19171927 by Mary Louise Roberts, and Manufacturing Inequality: Gender Division in the French and the British Metalworking Industries 1914-1931 by Laura Lee Downs (Vol. 17, No. 3-4, p. 180)

GUELDRY, Michel. Liberté, Égalité, Parité: deux femmes politiques témoignent. Review of Être femme en politique by Elisabeth Guigou and «On ne peut rien faire, Madame le ministre » by Corinne Lepage (Vol. 17, No. 2, p. 43)

GUELDRY, Michel. Où en est la République? Les Jacobins partent, les Girondins reviennent, l'Europe s'installe. Review of Les Jacobins de Robespierre à Chevènement by Michel Vovelle, Une ambition française by Alain Duhamel, and France in the European Union by Alain Guyomarch, Howard Machin, and Ella Ritchie (Vol. 18, No. 1, p. 101)

LEWIS, Helena. Surrealism Re-Viewed. Review of Surrealism: Two Private Eyes. The Nesuhi Ertegun and Daniel Filipacci Collections and Surreal Lives: The Surrealists 1917-1945 by Ruth Brandon (Vol. 18, No. 1, p. 105)

MAYER, Nonna. Reply to John W.P. Veugelers (Vol. 18, No. 1, p. 95)

PAXTON, Robert O. Gérard Noiriel's Third Republic. Review of Gérard Noiriel, Les Origines républicaines de Vichy (Vol. 18, No. 2, p. 99)

STOVALL, Tyler. Histories of Race in France. Review of On Human Diversity: Nationalism, Racism, and Exoticism in French Thought by Tzvetan Todorov, 
"There Are No Slaves in France": The Political Culture of Race and Slavery in the Ancien Régime by Sue Peabody, Imperial Identities: Stereotyping, Prejudice and Race in Colonial Algeria by Patricia M. E. Lorcin, and Deconstructing the Nation: Immigration, Racism and Citizenship in Modern France by Maxim Silverman (Vol. 18, No. 3, p. 137)

VEUGELERS, John W.P. Support for the Front national and Le Pen: Research Findings and Issues of Interpretation. Review of Ces Français qui votent FN by Nonna Mayer (Vol. 18, No. 1, p. 89)

\section{Book Reviews}

BAUMGARTNER, Frank R. How France Votes edited by Michael S. Lewis-Beck (Vol. 18, No. 2, p. 130)

BEASLEY, Faith E. From the Royal to the Republican Body: Incorporating the Political in Seventeenth- and Eighteenth-Century France edited by Sara E. Merlzer and Kathryn Norberg (Vol. 17, No. 1, p. 84)

BERISS, David. Les Manifestations en France: 1918 -1968 by Danielle Tartakowsky (Vol. 17, No, 2, p. 53)

BERNARD, Claudie. The Family in Crisis in Late Nineteenth-Century French Fiction by Nicholas White (Vol. 18, No. 2, p. 114)

CLEETON, David L. France on the Brink: A Great Civilization Faces the New Century by Jonathan Fenby (Vol. 18, No. 1, p. 130)

COGAN, Charles G. La Grandeur: politique étrangère du général de Gaulle, 1958-1969 by Maurice Vaïsse (Vol. 17, No. 1, p. 79)

ENGLUND, Steven. Déroulède, l'inventeur du nationalisme by Bertrand Joly (Vol. 17, No. 2, p. 65)

ESPOSITO, Chiarella. France Restored: Cold War Diplomacy and the Quest for Leadership in Europe, 1944-1954 by William I. Hitchcock (Vol. 18, No.1, p. 126)

FRIEND, Julius W. The Burden of Responsibility: Blum, Camus, Aron, and the French Twentieth Century by Tony Judt (Vol. 17, No. 2, p. 50)

GOLDHAMMER, Arthur. Le Monde des Débats edited by Michel Wieviorka (Vol. 18, No. 2, p. 134)

GOLSAN, Richard J. Modernity and Nostalgia: Art and Politics in France Between the Wars by Romy Golan (Vol. 18, No. 1, p. 118)

GUIRAUDON, Virginie. La France immigrée: construction d'une politique 19141997 by Vincent Viet (Vol. 17, No. 2, p. 47).

HARRISON, David. Unfinished Revolutions: Legacies of Upheaval in Modern French Culture edited by Robert T. Denommé and Roland H. Simon (Vol. 18 , No. 1, p. 112)

HYMAN, Paula E. Les Juifs dans la banlieue parisienne des années 20 aux années 50 by Jean Laloum (Vol. 18, No. 1, p. 116) 
LEBOVICS, Herman. The Politics of Cultural Policy in France by Kim Eling (Vol. 18, No. 2, p. 126)

MILLER, Mark M. L'Immigration et l'État-nation: à la recherche d'un modèle national by James F. Hollifield (Vol. 17, No. 1, p. 70)

NORD, Philip. Paris 1900: essai d'histoire culturelle by Christophe Prochasson (Vol. 18, No. 2, p. 117)

PARSONS, Craig. The Choice for Europe: Social Purpose and State Power from Messina to Maastricht by Andrew Moravcsik (Vol. 17, No. 1, p. 74)

REED-DANAHAY, Deborah. La Culture des sentiments: l'expérience télévisuelle des adolescents by Dominique Pasquier (Vol. 18, No. 2, p. 133)

REID, Donald. Martyred Village: Commemorating the 1944 Massacre at Oradour-sur-Glane by Sarah Farmer (Vol. 17, No. 2, p. 56)

REYNOLDS, Siân. Vichy et l'éternel féminin by Francine Muel-Dreyfus (Vol. 18 , No. 1, p. 121)

SMITH, Bonnie. Ready-to-Wear and Ready-to-Work: A Century of Industry and Immigrants in Paris and New York by Nancy L. Green (Vol. 18, No. 1, p. 114)

VICHNIAC, Judith. Uneasy Asylum: France and the Jewish Refugee Crisis, 19331942 by Vicki Caron (Vol. 18, No. 2, p. 120)

VINCENT, K. Steven. Paul Lafargue and the Flowering of French Socialism, 1882-1911 by Leslie Derfler (Vol. 17, No. 2, p. 61)

WAKEMAN, Rosemary. The Situationist City by Simon Sadler (Vol. 18, No. 2, p. 123)

INDEX OF BOOKS REVIEWED

AMSELLE, Jean-Loup. Vers un multiculturalisme français, l'empire de la coutume reviewed by Alice L. Conklin (Vol. 18, No. 3, p. 143)

BADINTER, Robert. Un antisémitisme ordinaire: Vichy et les avocats juifs (19401944) reviewed by Vicki Caron (Vol. 18, No. 2, p. 104)

BRANDON, Ruth. Surreal Lives: The Surrealists 1917-1945 reviewed by Helena Lewis (Vol. 18, No. 1, p. 105)

CARON, Vicki. Uneasy Asylum: France and the Jewish Refugee Crisis, 1933-1942 reviewed by Judith Vichniac (Vol. 18, No. 2, p. 120)

DENOMMÉ, Robert T. and SIMON Roland H. eds. Unfinished Revolutions: Legacies of Upheaval in Modern French Culture reviewed by David Harrison (Vol. 18, No. 1, p. 112)

DERFLER, Leslie. Paul Lafargue and the Flowering of French Socialism, 18821911 reviewed by Steven K. Vincent (Vol. 17, No. 2, p. 61)

DOWNS, Laura Lee. Manufacturing Inequality: Gender Division in the French and British Metalworking Industries 1914-1931 review by Laura L. Frader (Vol. 17, No. 3-4, p. 180)

DUHAMEL, Alain. Une ambition française reviewed by Michel Gueldry (Vol. 18 , No. 1, p. 101) 
ELING, Kim. The Politics of Cultural Policy in France reviewed by Herman Lebovics (Vol. 18, No. 2, p. 126)

FARMER, Sarah. Martyred Village: Commemorating the 1944 Massacre at Oradour-sur-Glane reviewed by Donald Reid (Vol. 17, No. 2, p. 56)

FENBY, Jonathan. France on the Brink: A Great Civilization Faces the New Century reviewed by David L. Cleeton (Vol. 18, No. 1, p. 130)

GOLAN, Romy. Modernity and Nostalgia: Art and Politics in France Between the Wars reviewed by Richard J. Golsan (Vol. 18, No. 1, p. 118)

GREEN, Nancy L. Ready-to-Wear and Ready-to-Work: A Century of Industry and Immigrants in Paris and New York reviewed by Bonnie Smith (Vol. 18, No. 1, p. 114)

GUIGOU, Élisabeth. Etre femme en politique reviewed by Michel Gueldry (Vol. 17, No. 2, p. 43)

GUYOMARCH, Alain, MACHIN Howard and RITCHIE Ella. France in the European Union reviewed by Michel Gueldry (Vol. 18, No. 1, p. 101)

HARGREAVES, Alec G. and McKINNEY, Mark, eds. Post-Colonial Cultures in France reviewed by Alice L. Conklin (Vol. 18, No. 3, p. 152)

HITCHCOCK, William I. France Restored: Cold War Diplomacy and the Quest for Leadership in Europe, 1944-1954 reviewed by Chiarella Esposito (Vol. 18, No.1, p. 126)

HOLLIFIED, James F. L'Immigration et l'État-nation: à la recherche d'un modèle national reviewed by Mark M. Miller (Vol. 17, No. 1, p. 70)

JOLY, Bertrand. Déroulède, l'inventeur du nationalisme reviewed by Steven Englund (Vol. 17, No. 2, p. 65)

JUDT, Tony. The Burden of Responsibility: Blum, Camus, Aron, and the French Twentieth Century reviewed by Julius W. Friend (Vol. 17, No. 2, p. 50)

LALOUM, Jean. Les Juifs dans la banlieue parisienne des années 20 aux années 50 reviewed by Paula E. Hyman (Vol. 18, No. 1, p. 116)

LEPAGE, Corinne. "On ne peut rien faire, Madame le ministre » reviewed by Michel Gueldry (Vol. 17, No. 2, p. 43)

LEWIS-BECK, Michael, ed. How France Votes reviewed by Frank R. Baumgartner (Vol 18, No. 2, p. 130)

LORCIN, Patricia M. E. Imperial Identities: Stereotyping, Prejudice and Race in Colonial Algeria reviewed by Tyler Stovall (Vol 18, No. 3, p. 137)

MAYER, Nona. Ces Français qui votent FN reviewed by John W. P. Veugelers (Vol. 18, No. 1, p. 89)

MERLZER, Sara E. and NORBERG Kathryn, eds. From the Royal to the Republican Body: Incorporating the Political in Seventeenth- and EighteenthCentury France reviewed by Faith E. Beasley (Vol. 17, No. 1, p. 84)

MORAVCSIK, Andrew. The Choice for Europe: Social Purpose and State Power from Messina to Maastricht reviewed by Craig Parsons (Vol. 17, No. 1, p. 74)

MUEL-DREYFUS, Francine. Vichy et l'éternel féminin reviewed by Siân Reynolds (Vol. 18, No. 1, p. 121) 
NOIRIEL, Gérard. Les Origines républicaines de Vichy reviewed by Robert O. Paxton (Vol. 18, No. 2, p. 99)

PASQUIER, Dominique. La Culture des sentiments: l'expérience télévisuelle des adolescents reviewed by Deborah Reed-Danahay (Vol. 18, No. 2, p. 133)

PEABODY, Sue. "There Are No Slaves in France": The Political Culture of Race and Slavery in the Ancien Régime, reviewed by Tyler Stovall (Vol. 18, No. 3, p. 137)

PROCHASSON, Christophe. Paris 1900: essai d'histoire culturelle reviewed by Philip Nord (Vol. 18, No. 2, p. 117)

REYNOLDS, Siân. France Between the Wars: Gender and Politics reviewed by Laura L. Frader (Vol. 17, No. 3-4, p. 180)

ROBERTS, Mary Louise. Civilization Without Sexes: Reconstructing Gender in Postwar France, 1917-1927 reviewed by Laura L. Frader (Vol. 17, No. 3-4, p. 180)

SADLER, Simon. The Situationist City reviewed by Rosemary Wakeman (Vol. 18 , No. 2, p. 123)

SILVERMAN, Maxim. Deconstructing the Nation: Immigration, Racism and Citizenship in Modern France reviewed by Tyler Stovall (Vol. 18, No, 3, p. 137)

[no author - catalogue for art exhibit] Surrealism: Two Private Eyes. The Nesuhi Ertegun and Daniel Filipacci Collections reviewed by Helena Lewis (Vol. 18, No. 1, p. 105)

TARTAKOWSKY, Danielle. Les Manifestations en France: 1918-1968 reviewed by David Beriss (Vol. 17, No, 2, p. 53)

TODOROV, Tzvetan. On Human Diversity: Nationalism, Racism, and Exoticism in French Thought reviewed by Tyler Stovall (Vol. 18, No. 3, p. 137)

VAÏSSE, Maurice. La Grandeur: politique étrangère du général de Gaulle, 19581969 reviewed by Charles Cogan (Vol. 17, No. 1, p 79)

VIET, Vincent. La France immigrée: construction d'une politique 1914-1997 reviewed by Virginie Guiraudon (Vol. 17, No. 2, p. 47).

VOVELLE, Michel. Les Jacobins de Robespierre à Chevènement reviewed by Michel Gueldry (Vol. 18, No. 1, p. 101)

WEISBERG, Richard H. Vichy Law and The Holocaust in France reviewed by Vicki Caron (Vol. 18, No. 2, p. 104)

WHITE, Nicholas. The Family in Crisis in Late Nineteenth-Century French Fiction reviewed by Claude Bernard (Vol. 18, No. 2, p. 114)

WIEVIORKA, Michel, ed. Le Monde des Débats reviewed by Arthur Goldhammer (Vol. 18, No. 2, p. 134)

\section{Film RevieW}

DREYFUS, Muriel. Voyages by Emmanuel Finkiel (Vol. 18, No. 1, p. 131) 